\title{
Comparative Study on Advanced Nitrogen Removal of Landfill Leachate Treated by SBR and SBBR
}

\author{
Jinfeng Jiang ${ }^{1}$, Liang $\mathrm{Ma}^{2}$, Lianjie Hao ${ }^{2}$, Daoji $\mathrm{Wu}^{1}$ and Kai Wang ${ }^{1, *}$ \\ 1 School of Municipal and Environmental Engineering, Shandong Jianzhu University, 1000 Fengming Street, \\ Jinan 250101, China; 2019045102@stu.sdjzu.edu.cn (J.J.); wdj@sdjzu.edu.cn (D.W.) \\ 2 Shandong Guochen Industrial Group Co., Ltd., Wangui Road, Jinan 250305, China; \\ guochenshiye@163.com (L.M.); 13361057808@163.com (L.H.) \\ * Correspondence: wangkai@sdjzu.edu.cn
}

check for updates

Citation: Jiang, J.; Ma, L.; Hao, L.; Wu, D.; Wang, K. Comparative Study on Advanced Nitrogen Removal of Landfill Leachate Treated by SBR and SBBR. Water 2021, 13, 3240. https:// doi.org/10.3390/w13223240

Academic Editors: Carmen Teodosiu and Antonio Panico

Received: 14 October 2021

Accepted: 12 November 2021

Published: 16 November 2021

Publisher's Note: MDPI stays neutral with regard to jurisdictional claims in published maps and institutional affiliations.

Copyright: (c) 2021 by the authors. Licensee MDPI, Basel, Switzerland. This article is an open access article distributed under the terms and conditions of the Creative Commons Attribution (CC BY) license (https:// creativecommons.org/licenses/by/ $4.0 /)$.

\begin{abstract}
In order to achieve advanced nitrogen removal from landfill leachate without the addition of external carbon sources, a Sequencing Batch Reactor (SBR) and a Sequencing Biofilm Batch Reactor (SBBR) were proposed for the treatment of actual landfill leachate with ammonia nitrogen $\left(\mathrm{NH}_{4}^{+}-\mathrm{N}\right)$ and chemical oxygen demand (COD) concentrations of $1000 \pm 100 \mathrm{mg} / \mathrm{L}$ and $4000 \pm 100 \mathrm{mg} / \mathrm{L}$, respectively. The operating modes of both systems are anaerobic-aerobic-anoxic. After 110 days of start-up and biomass acclimation, the effluent COD and the total nitrogen (TN) of the two systems were $650 \pm 50 \mathrm{mg} / \mathrm{L}$ and $20 \pm 10 \mathrm{mg} / \mathrm{L}$, respectively. The removal rates of COD and total nitrogen could reach around $85 \%$ and above $95 \%$, respectively. Therefore, advanced nitrogen removal was implemented in landfill leachate without adding any carbon sources. After the two systems were acclimated, nitrogen removing cycles of SBR and SBBR were $24 \mathrm{~h}$ and $20 \mathrm{~h}$, respectively. The nitrogen removing efficiency of SBBR was improved by $16.7 \%$ in comparison to SBR. In the typical cycle of the two groups of reactors, the nitrification time of the system was the same, which was $5.5 \mathrm{~h}$, indicating that although the fiber filler occupied part of the reactor space, it had no significant impact on the nitrification performance of the system. At the end of aeration, the internal carbon source content of sludge of SBBR was equivalent to that of the SBR system. However, the total nitrogen concentration of SBBR was only $129 \mathrm{mg} / \mathrm{L}$, which is $33.8 \%$ lower than that of SBR at $195 \mathrm{mg} / \mathrm{L}$. The main reason was that biofilm enhanced the simultaneous nitrification and denitrification (SND) effect of the system.
\end{abstract}

Keywords: landfill leachate; SBR; SBBR; advanced nitrogen removal; simultaneous nitrification and denitrification

\section{Introduction}

With the development of the world economy, increasing generation of solid waste can be witnessed. Many developing countries, especially China, treat solid waste by means of solid waste landfills [1]. Rainwater percolating through the landfill, together with the production of liquids during the stabilization of the solid wastes, generates landfill leachate. This is a particular type of wastewater with complex composition, high organic matter, high ammonia nitrogen, and high salt content, which has always been a difficult point and highlight in the water treatment industry [1,2].

One of the difficulties in landfill leachate treatment is advanced nitrogen removal. Some researchers have treated landfill leachates utilizing ammonia stripping or adsorption, but the effluent fails to reach the discharge standard [3,4]. The biochemical process has always been a core process to implement in advanced nitrogen removal due to its good effect and low cost [5-9]. At present, the biological nitrogen removal technology is composed of nitrification and denitrification, partial nitrification-denitrification, and anaerobic ammonia oxidation [10-13]. At present, an anaerobic-oxic (AO) process has been frequently adopted to achieve partial nitrification-denitrification in most of the research on landfill 
leachate treatment [14]. The changing process has a good effect on the ammonia-nitrogen removal of leachates. However, the removal rate of the total nitrogen is unlikely to exceed $95 \%$ [15]. In recent years, some researchers have achieved good effects in the treatment of advanced nitrogen removal of landfill leachate using endogenous denitrification with the total nitrogen removal rate stably reaching over $95 \%$, the principle of which is to utilize the feature that microorganisms can store polyhydroxyalkanoates (PHA) to implement advanced nitrogen removal in the leachate by endogenous respiration [16-18]. PHA is an essential internal carbon source in the metabolic activities of microorganisms [19]. Some microorganisms can convert organic matters in the wastewater into PHA and store it for the carbon source of denitrification [20]. Beyond that, PHA plays a vital role in the simultaneous nitrification and denitrification (SND) process [21,22]. However, simultaneous nitrification and denitrification have a weak function in the traditional SBR [23]. Some researchers have improved the system's simultaneous nitrification and denitrification by reducing dissolved oxygen during Sequencing Batch Reactor (SBR) aeration [24]. However, low dissolved oxygen affects the nitrification efficiency of SBR. Therefore, an aerobic-anoxic microenvironment will be formed in the aeration process of SBBR in the presence of biofilm, with the high efficiency of SND [25]. At the same time, the presence of biofilm can contribute to protecting the internal carbon source such as PHA inside the denitrifying bacteria.

This study was designed for: (1) observing the effects of the advanced nitrogen removal of landfill leachate using SBR and Sequencing Biofilm Batch Reactor (SBBR), (2) observing the variations of chemical oxygen demand (COD), total nitrogen, ammonia nitrogen, nitrate nitrogen, nitrite nitrogen, and PHA of SBR and SBBR in one cycle, and (3) analyzing its internal causes by comparing the efficiency and effect of SBR and SBBR on the nitrogen removal of leachate.

\section{Materials and Methods}

\subsection{Experimental Setup}

A polymethyl methacrylate SBBR and SBR reactor was used for the experiments, as shown in Figure 1. A laboratory-scale cylindrical SBBR and SBR with a height of $50 \mathrm{~cm}$, diameter of $20 \mathrm{~cm}$, and a working volume of $10 \mathrm{~L}$ were used. The SBBR and SBR included a Multi 3620 analyzer for the detection of potential of hydrogen $(\mathrm{pH})$, dissolved oxygen (DO), and oxidation-reduction potential (ORP), mechanical stirrers, an air diffuser, an air compressor, a heating belt, and a temperature control box. The air diffuser was connected to the air compressor for the aeration of the reactors. The heating belt and temperature control box constitute a temperature control device to regulate the temperature. The biofilm filler consists of polyurethane and other polymer materials, referred to as Poly Propylene Carbonate (PPC), and the PPC characteristics are shown in Table 1.
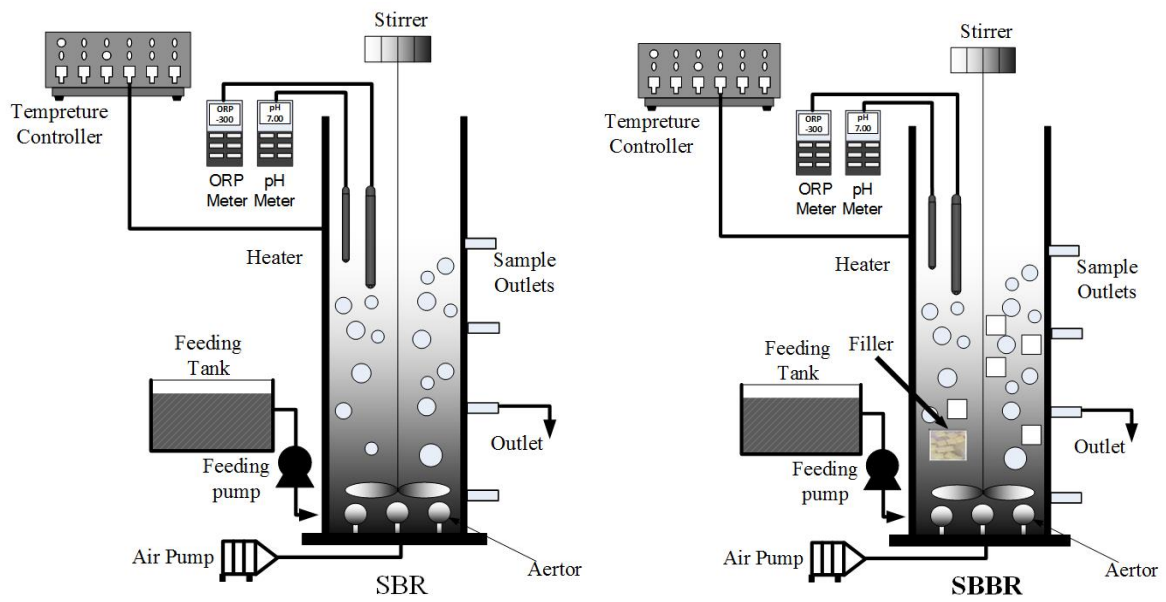

Figure 1. Schematic diagrams of the SBR and SBBR device. 
Table 1. The characteristics of PPC.

\begin{tabular}{cccccc}
\hline Item & $\begin{array}{c}\text { Edge Length } \\
(\mathbf{m m})\end{array}$ & $\begin{array}{c}\text { Density } \\
\left(\mathbf{k g ~ m} \mathbf{~ m}^{-\mathbf{3}}\right)\end{array}$ & $\begin{array}{c}\text { Surface Area } \\
\left(\mathbf{m}^{\mathbf{2}} \mathbf{~ m}^{-\mathbf{1}}\right)\end{array}$ & Porosity (\%) & $\begin{array}{c}\text { Hanging Film Time } \\
(\mathbf{D a y s})\end{array}$ \\
\hline Parameter & $10 \pm 1$ & $12.5 \pm 0.7$ & $>4000$ & 98 & $3-7$ \\
\hline
\end{tabular}

\subsection{Influent Media, Sludge and Filler}

Raw landfill leachate for this study was taken from the Ji Yang Municipal Solid Waste (MSW) Sanitation Landfill Site, Jinan, Shandong Province, China. The landfill leachate was taken once a month and we used closed plastic barrels for sampling and transportation. After sampling, leachate was stored in a refrigerated environment at $4{ }^{\circ} \mathrm{C}$ to reduce the impact of microorganisms on it. The characteristics of the landfill leachate are shown in Table 2. The seed sludge was obtained from return sludge from the Everbright Sewage Treatment Plant, Jinan, Shandong Province, China. The concentrations of mixed liquid suspended solids (MLSS), mixed liquor volatile suspended solids (MLVSS), and the sludge volume index (SVI) were approximately $9230 \mathrm{mg} / \mathrm{L}, 7523 \mathrm{mg} / \mathrm{L}$, and $123 \mathrm{~mL} / \mathrm{g}$, respectively.

Table 2. The characteristics of the leachate.

\begin{tabular}{ccccccc}
\hline Item & $\mathbf{p H}$ & $\begin{array}{c}\mathbf{N H}_{4}^{+}-\mathbf{N} \\
(\mathbf{m g} / \mathrm{L})\end{array}$ & $\begin{array}{c}\mathrm{TN} \\
(\mathbf{m g} / \mathrm{L})\end{array}$ & $\begin{array}{c}\mathbf{N O}_{\mathbf{x}}^{-}-\mathbf{N} \\
(\mathbf{m g} / \mathrm{L})\end{array}$ & $\begin{array}{c}\mathrm{COD} \\
(\mathbf{m g} / \mathbf{L})\end{array}$ & $\begin{array}{c}\text { BOD5 } \\
(\mathbf{m g} / \mathbf{L})\end{array}$ \\
\hline Range & $8.0 \pm 0.3$ & $1000 \pm 100$ & $1100 \pm 100$ & $0.11 \sim 0.8$ & $4000 \pm 100$ & $2000 \pm 100$ \\
\hline
\end{tabular}

\subsection{Operational Procedure}

The operation mode of the SBBR system includes: (a) a filling phase (5 min); (b) a pre-anoxic phase (60 $\mathrm{min}) ;(\mathrm{c})$ an aeration phase (aeration time); (d) an anoxic phase (anoxic time); (e) a settling phase ( $30 \mathrm{~min})$; (f) an effluence phase (5 min); and (g) an idle phase (idle time). The aeration time and anoxic time were determined from the ammonium valley ( $\mathrm{pH}$ variation) and nitrate knee (ORP variation) real-time control methods. The volumetric exchange rate was $30 \%$. The temperature was controlled at $25 \pm 1{ }^{\circ} \mathrm{C}$. Between the air diffuser and the air compressor, the aeration volume was controlled by the rotameter, and the dissolved oxygen concentration was detected by the Multi 3620 analyzer. Air was used for aeration and the flow rate of the gas mixture was from to $0.4 \mathrm{~m}^{3} / \mathrm{h} \sim 4 \mathrm{~m}^{3} / \mathrm{h}$. The DO concentration was maintained over a range from $2.0 \mathrm{mg} / \mathrm{L}$ to $4.0 \mathrm{mg} / \mathrm{L}$ during the aeration phase.

\subsection{Method Determination and Calculations}

The $\mathrm{pH}, \mathrm{DO}, \mathrm{ORP}$, and temperature were monitored using a Multi 3620 analyzer (WTW Company, Weilheim, Germany). Ammonia nitrogen $\left(\mathrm{NH}_{4}^{+}-\mathrm{N}\right)$, nitrite $\left(\mathrm{NO}_{2}^{-}-\mathrm{N}\right)$, nitrate $\left(\mathrm{NO}_{3}^{-}-\mathrm{N}\right)$, chemical oxygen demand (COD), MLSS, MLVSS, and the SVI were measured using standard methods [26]. The total nitrogen (TN) was analyzed using a TN analyzer (Multi N/C3000, Analytik Jena GmbH, Jena, Germany). The extraction of polyhydroxyalkanoates (PHAs) was performed using the method described in Albuquerque et al. [27].

\section{Result and Discussion}

\subsection{Removal of Landfill Leachate COD by SBR and SBBR}

The test was performed for 110 days. Since the inoculated sludge was municipal sludge, the test was acclimated by gradually increasing the influent loading. The acclimated time was 70 days for both SBR and SBBR. Nitrification time was used as an index of inspection during acclimation. When the nitrification time was stable for more than 3 days, the influent loading was improved continuously before the influent was the stock solution of landfill leachate. The degrading situations of COD in landfill leachates treated by SBR 
and SBBR in the whole test are shown in Figure 2. As can be seen from Figure 2, the effluent COD increases accordingly with the increase of inflow COD of the leachate. The removal rates of the COD in landfill leachates for both reactors are almost equivalent, maintaining between $80 \%$ and $90 \%$. Finally, the effluent COD of both reactors were stabilized at $650 \pm 50 \mathrm{mg} / \mathrm{L}$, with the removal rate of organic matter expressed as COD of the leachate stabilized at about $85 \%$.

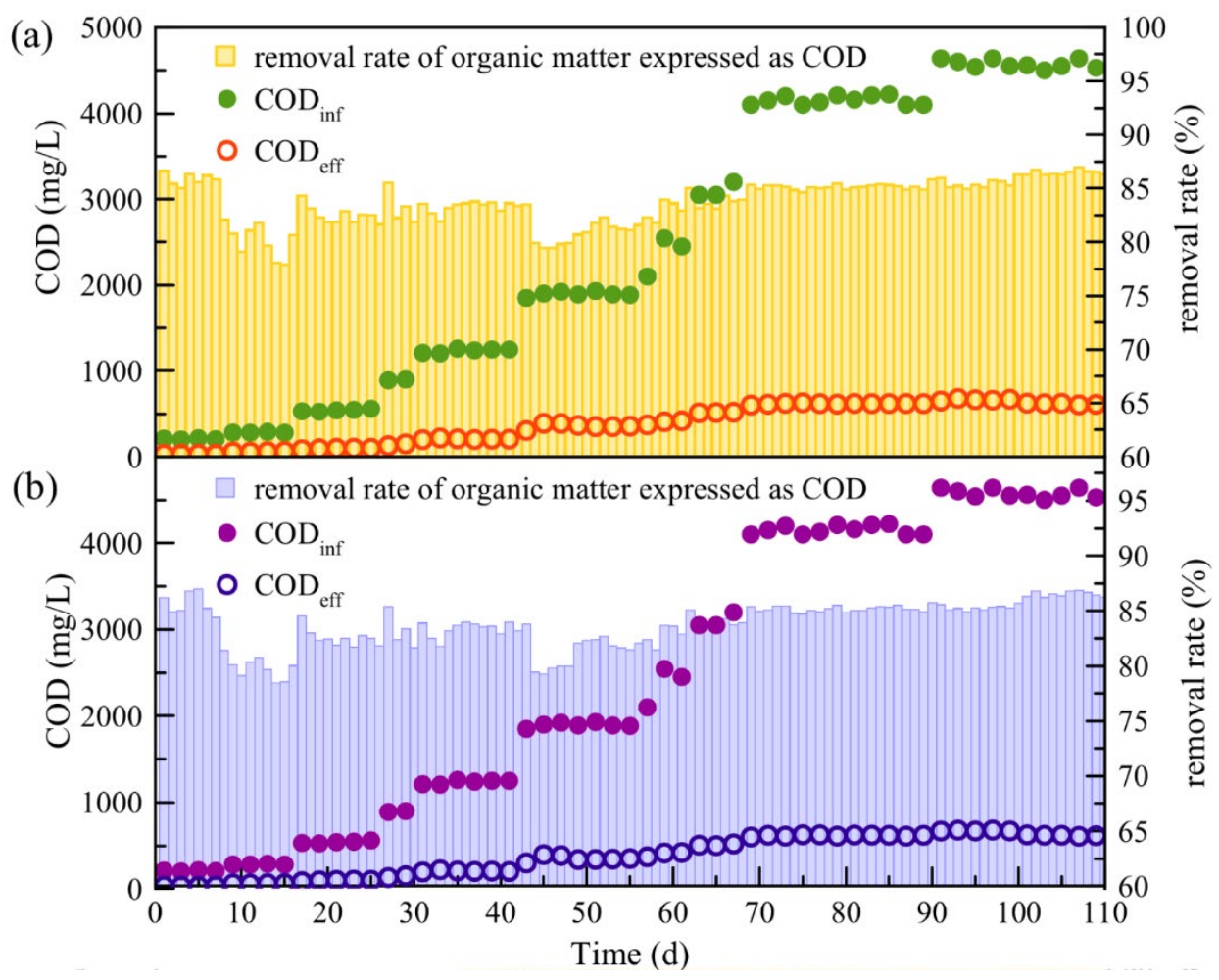

Figure 2. Removal of COD from landfill leachate by (a) SBBR; (b) SBR.

\subsection{Removal of Landfill Leachate $T N$ by SBR and SBBR}

The total nitrogen removal from landfill leachates with SBR and SBBR during the test is shown in Figure 3. As can be seen from Figure 3, the total nitrogen after system aeration was almost consistent with the total nitrogen of the final effluent in the first 30 days of the test. This was mainly because the denitrifying bacteria were not enriched at the early stage, exerting a limited effect of endogenous denitrification. Nitrification and denitrifying bacteria of the two systems were enriched as the test continued. The effect of endogenous denitrification became significant with the shortened time of nitrification. The nitrification time was increased after improving loading each time. However, after that, the nitrification time was gradually shortened and eventually stabilized at the range from $4 \mathrm{~h}$ to $5 \mathrm{~h}$. In the meantime, the enrichment of denitrifying bacteria also contributed to the improved effect of SND and endogenous denitrification so that the total nitrogen in the effluent of both systems could be maintained at $50 \mathrm{mg} / \mathrm{L}$ during the whole test with the removal rate of total nitrogen being stabilized at above $90 \%$. After comparing Figure $3 a$ with Figure $3 b$, it can be found that the total nitrogen amounts of the two reactors after aeration are completely different at the later test stage, although the total effluent nitrogen of the two reactors has little difference. After 60 days of the test, the total nitrogen was increased after the aeration of SBR. Nevertheless, the total nitrogen of SBBR was still maintained at a low level. This was directly related to the better SND effect caused by the biofilm of SBBR. Moreover, although nitritation was achieved by both reactors, the SBBR reactor achieved partial nitrification at a faster time. The accumulation rate of nitrous acid reached above $50 \%$ after 45 days of the SBR test, whereas the SBBR achieved partial 
nitrification on the 30th day of the test. Under the condition of consistent total nitrogen concentration in the influent, SBBR achieved partial nitrification 15 days earlier than the SBR. This may be related to the more complex sludge environment in SBBR. In the second half of the test, both systems arrived at a stable period with the total nitrogen concentration in the inflow maintaining at $1000 \mathrm{mg} / \mathrm{L}$. The advanced nitrogen removal of landfill leachate could be implemented by both SBR and SBBR through changing the operation mode with the effluent total nitrogen less than $50 \mathrm{mg} / \mathrm{L}$, and the total nitrogen removal rate reaching above $95 \%$ without any external carbon source.

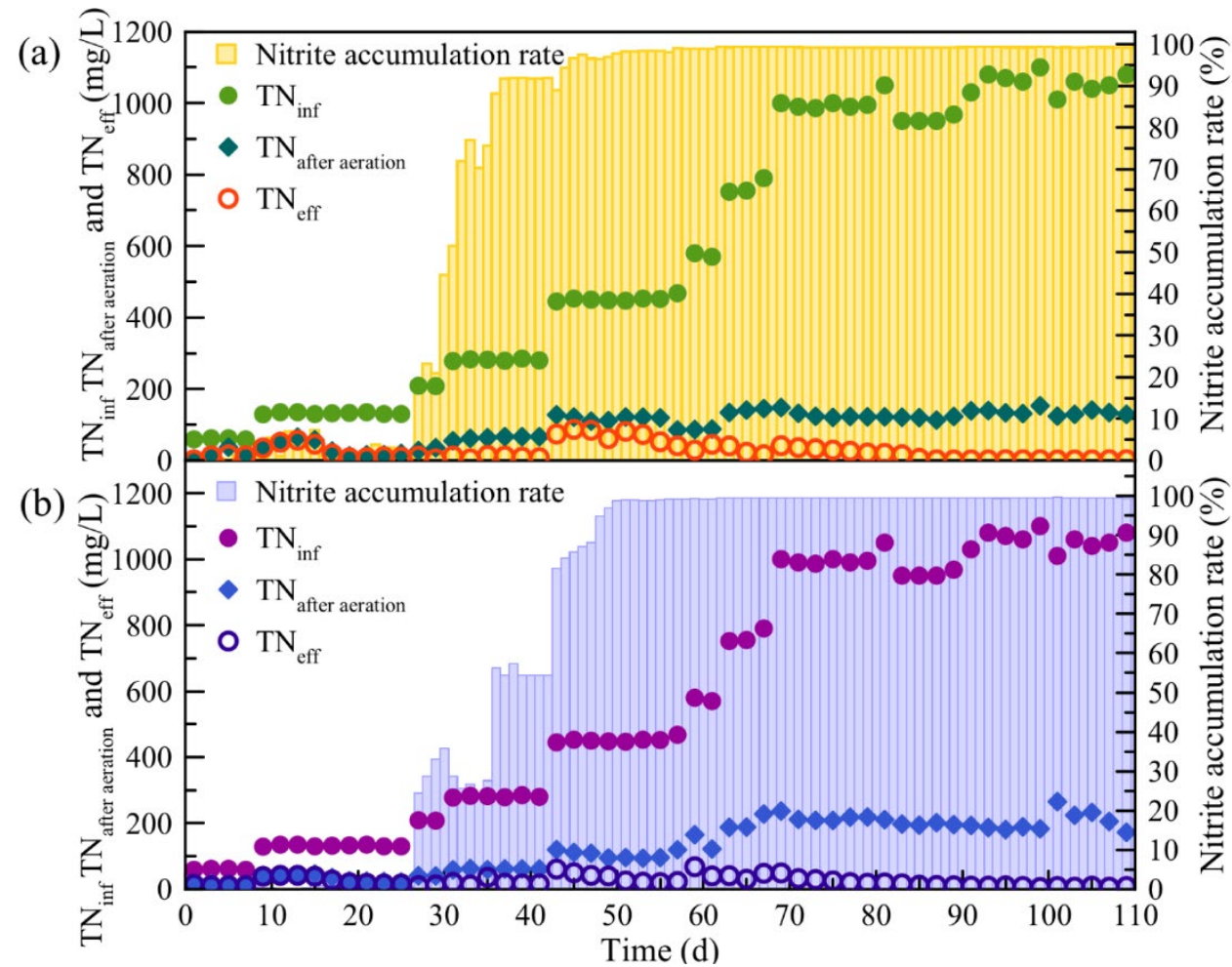

Figure 3. Removal of TN from landfill leachate by (a) SBBR; (b) SBR. (TN $\mathrm{Tnf}_{\text {: }}$ total nitrogen concentration of influent; $\mathrm{TN}_{\mathrm{eff}}$ : total nitrogen concentration of effluent.).

The composition of nitrogen removal of landfill leachate using SBR and SBBR is shown in Figure 4. The nitrogen removal of leachate with these two systems was composed of SND and endogenous denitrification (ED) since the operating modes of SBR and SBBR are changed. As can be seen from Figure 3a, the capability of nitrogen removal of the whole system is weak at an early stage. The nitrogen removal situations of the two systems are similar. From the 50th day, the advantages of biofilm in SBBR can be witnessed gradually, and the amount of SND was higher than that of SBR. After 70 days, the test reached a stable period. The amount of SND of SBBR was further improved in comparison to SBR. The nitrogen removal amount ranged $150 \mathrm{mg} / \mathrm{L}$ to $160 \mathrm{mg} / \mathrm{L}$, where SND can be implemented through the aerobic-anoxic microenvironment of biofilm in SBBR, which was up by $40-50 \%$ in comparison to $100 \mathrm{mg} / \mathrm{L}$ to $110 \mathrm{mg} / \mathrm{L}$ in SBR. Since the total nitrogen in the leachate was constant, the amount of nitrogen that was removed by the ED of SBBR was less than that of SBR at the same stage. 


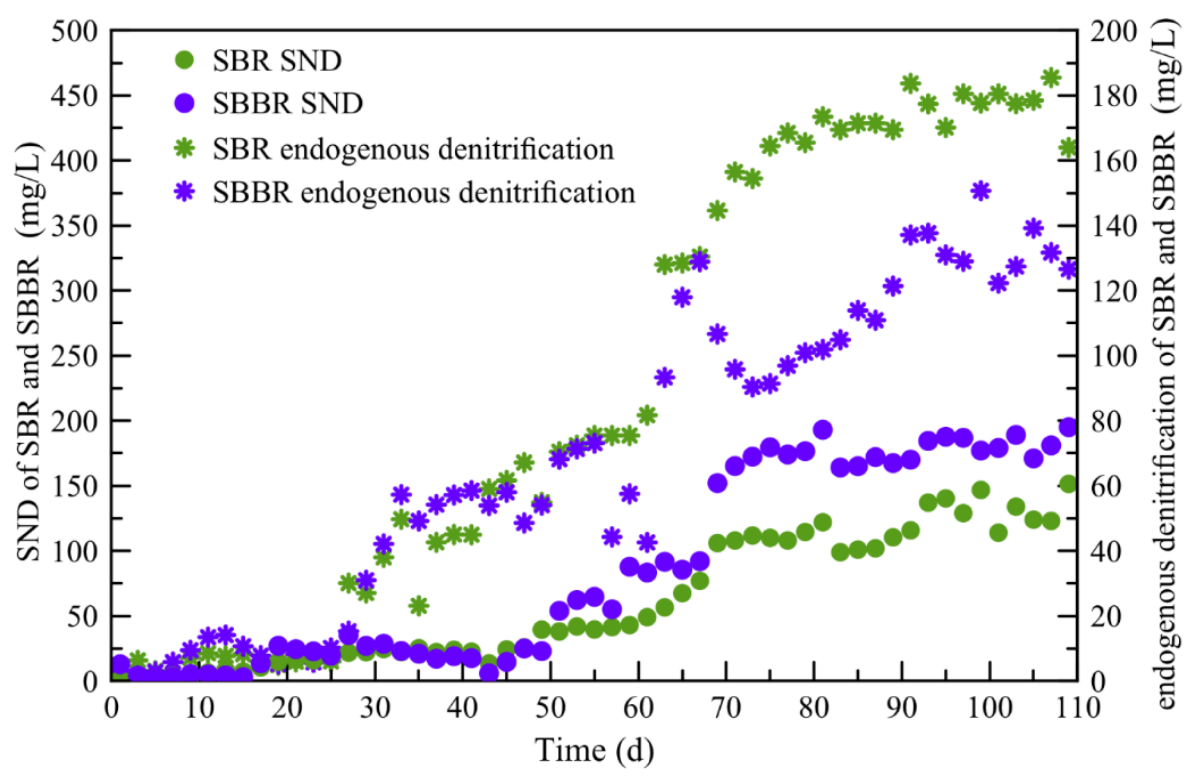

Figure 4. Comparison of nitrogen removal methods between SBR and SBBR.

Because of the stuffing and biofilm in SBBR, more internal carbon sources could be used for highly efficient SND than SBR and more internal carbon source of denitrifying bacteria was kept after nitrification. Therefore, the nitrogen removal efficiency of the whole system of SBBR was also higher than that of SBR. The duration of the reaction cycle for the SBR and SBBR was shown in Figure 5. In the first 84 days of the test, the duration of the reaction cycle was $24 \mathrm{~h}$ for SBR and SBBR. Nevertheless, the nitrogen removal efficiency of SBBR was gradually increasing and the nitrogen removal time was getting shorter as the biofilm was increased constantly. The cycle time was stabilized at $20 \mathrm{~h}$ after the 98th day of the test. The nitrogen removal efficiency of SBBR was up by $16.7 \%$ in comparison to SBR. When the nitrogen removal effect was consistent, the shorter period indicates that SBBR had higher efficiency of nitrogen removal than SBR. The nitrogen removal effect of the system could be strengthened by adding biological stuffing.

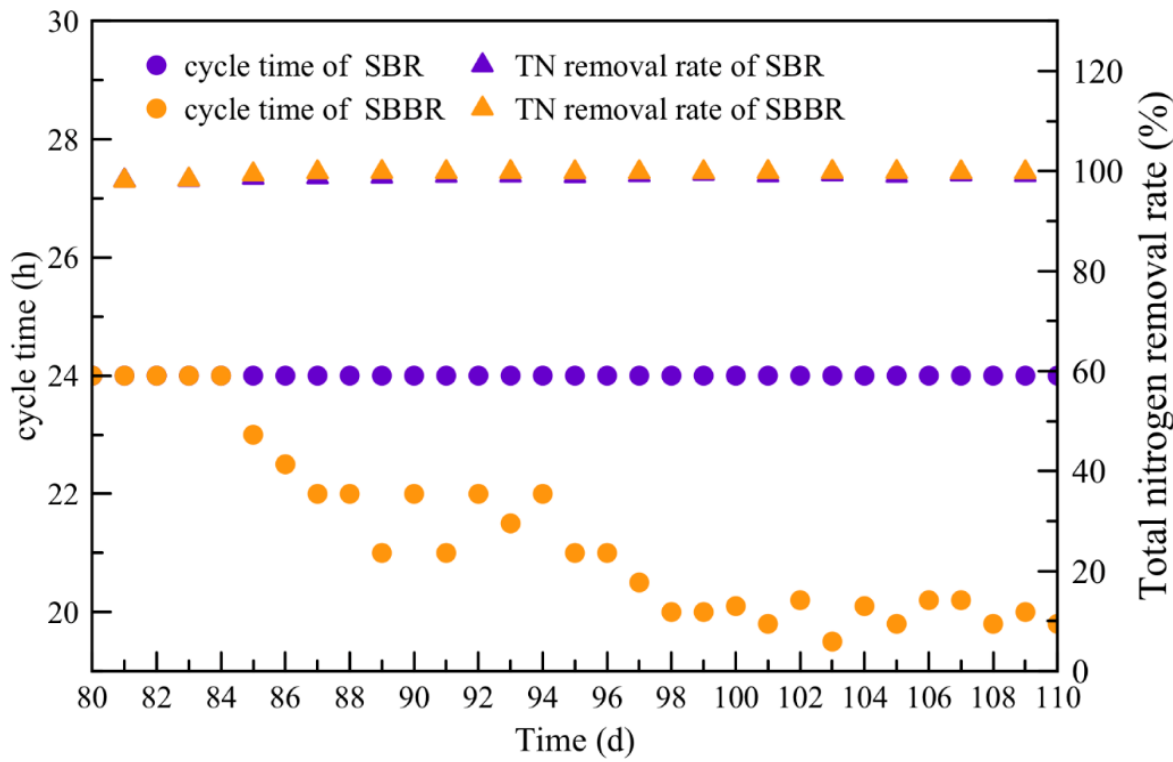

Figure 5. Comparison of reaction cycles between SBR and SBBR. 


\subsection{The Change of Pollutants in One Cycle of SBR and SBBR}

When the nitrogen removal efficiency of SBR was stabilized, variations of SBR pollutants and PHA in a cycle were monitored. Results were shown in Figure 6. It can be observed from Figure 6 that there was a large decrease in COD of the system within $1 \mathrm{~h}$ of anaerobic stirring. The main reason for the decrease of COD was that during the mixing process, the organic matter in the sewage would be first adsorbed to the cell wall by microorganisms, and then enter the cell through the cell membrane to form an internal carbon source.

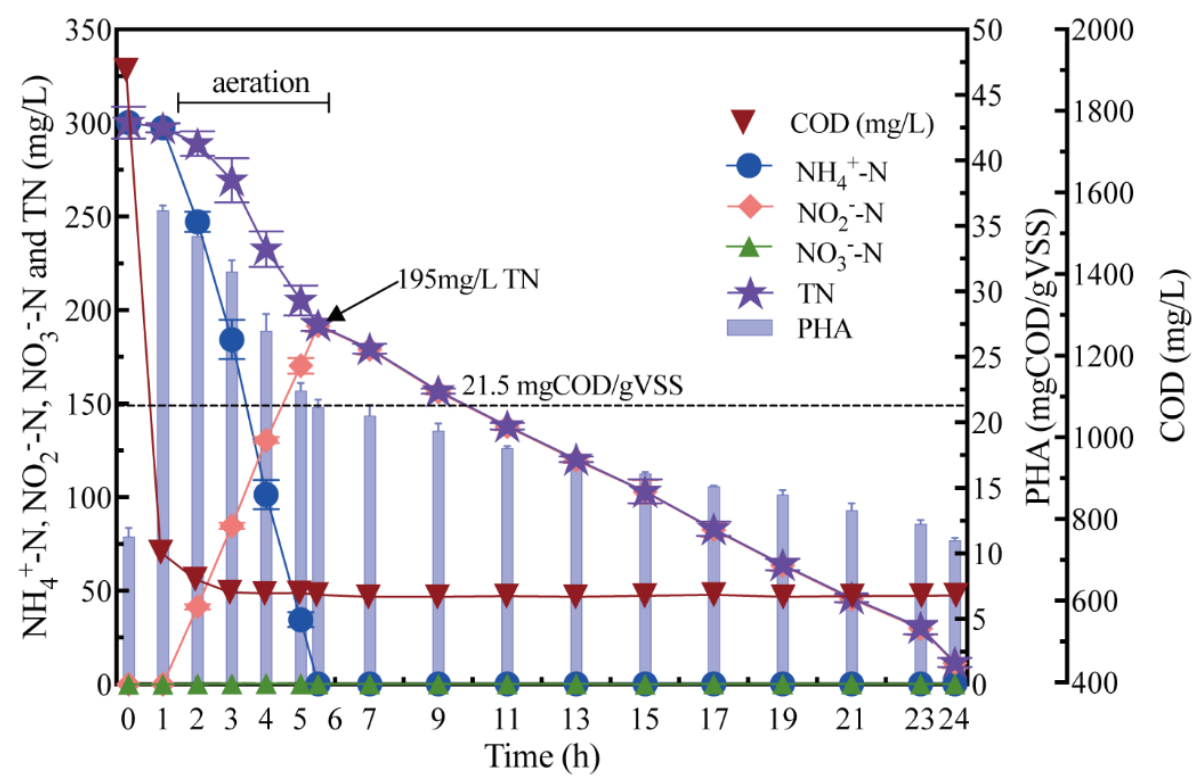

Figure 6. The variation of indices over typical cycles of stability period of SBR.

The amount of PHA in bacteria was changed from average $11 \mathrm{mg}$ COD/gVSS at the early stage of reaction to average $36 \mathrm{mg}$ COD/gVSS after stirring. A large amount of internal carbon in the sludge could not only provide a good foundation for the subsequent SND but also allow the system to involve in nitrification quickly, saving energy. After the start of aeration, the ammonia nitrogen was dropped drastically. The nitrification was completed in $5.5 \mathrm{~h}$. At this moment, the total nitrogen in the system was mainly composed of nitrite nitrogen, whose concentration reached $190 \mathrm{mg} / \mathrm{L}$. It was worth noting that the ammonia nitrogen of the system was average $296 \mathrm{mg} / \mathrm{L}$ after the influent mixing, while the total nitrogen was reduced to average $195 \mathrm{mg} / \mathrm{L}$ after the aeration, indicating that SND of about $100 \mathrm{mg} / \mathrm{L}$ occurred in the system. The PHA of the system was dropped continuously while the total nitrogen in the leachate started to drop at the subsequent stirring stage. After the test was carried out for $24 \mathrm{~h}$, most of the nitrite of the system was removed, indicating that the whole reaction was completed. At this moment, the PHA content of the internal carbon source of the sludge was resumed to average $11 \mathrm{mg}$ COD/gVSS before water inflow.

When the nitrogen removal efficiency of SBBR was stabilized, variations of SBBR pollutants and PHA in a cycle were monitored. Results are shown in Figure 7. The degradation law of pollutants by SBBR was basically the same as that of SBR, including the reduction of COD in anaerobic mixing section, the increase of carbon source in sludge and the time of nitrification. Being different from the SBR system, the total nitrogen concentration of the SBBR system was only average $129 \mathrm{mg} / \mathrm{L}$ by the end of aeration, which showed that SND of $170 \mathrm{mg} / \mathrm{L}$ occurred in the system. The function of SND in the system increased significantly in the presence of stuffing. The PHA of the system dropped continuously while the total nitrogen in the leachate started to drop at the subsequent stirring stage. After the test was carried out for $19 \mathrm{~h}$, the nitrous nitrite of the system 
was removed, indicating that the whole reaction was completed. At this moment, the PHA content of the internal carbon source of the sludge was resumed to about $11 \mathrm{mg}$ COD/gVSS before water inflow. Thus, the increase of stuffing enhances the nitrogen removal effect of the system rather than accelerating the nitrification time of the system. Zhu et al. treated landfill leachate by intermittent aeration SBR reactor, and the treatment concentration was equivalent to that in this paper. The results of this study show that with the addition of intermittent aeration, the system has completed deep denitrification in about $18 \mathrm{~h}$, and the treatment effect and cycle time were similar to that of this study. However, the intermittent aeration method was complex and difficult to apply. In this paper, SBBR has more application advantages [16].

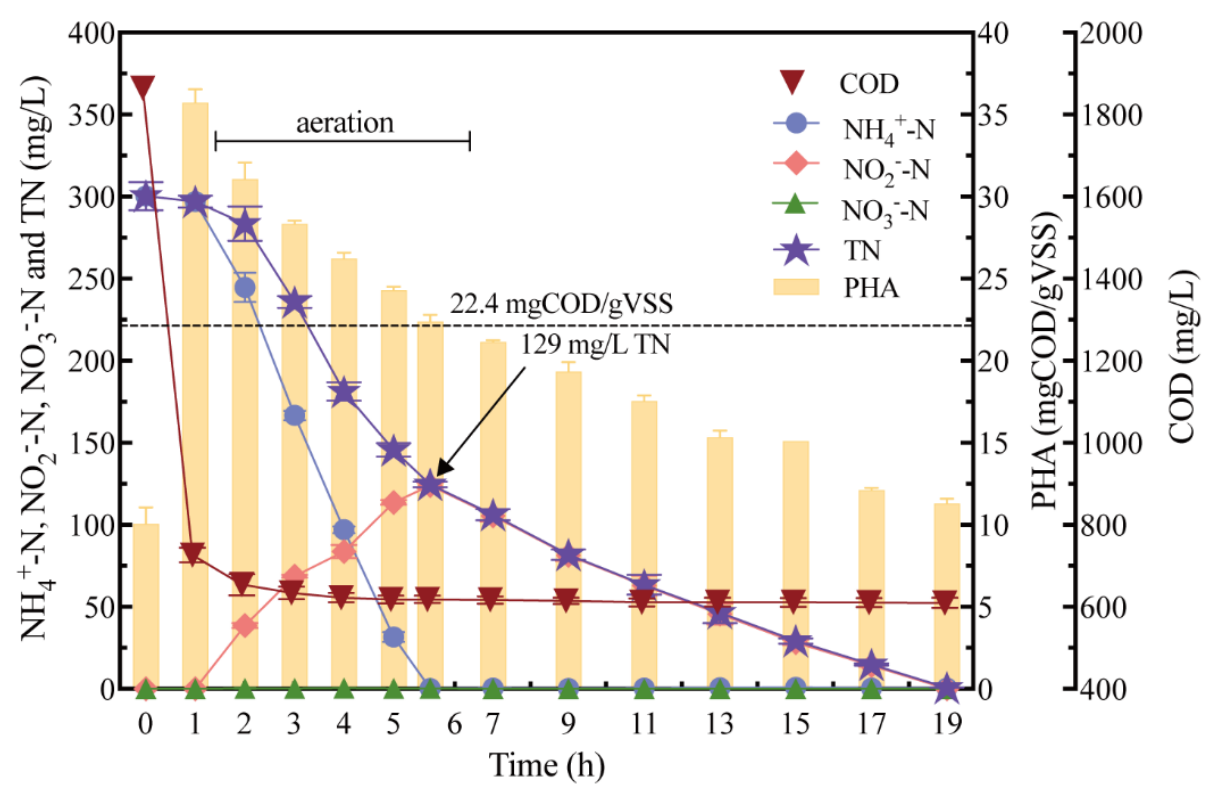

Figure 7. The variation of indices over typical cycles of stability period of SBBR.

By comparing Figure 5 with Figure 6, it can be observed that the two systems have two different points in one cycle. The first one was the total nitrogen removal rate and the PHA content of the sludge after nitrification. Although the nitrification times of both systems are $5.5 \mathrm{~h}$, the total nitrogen content of SBBR at the end of nitrification was only $129 \mathrm{mg} / \mathrm{L}$ since the biofilm structure of SBBR allows the denitrifying bacteria to perform SND, which was $66 \mathrm{mg} / \mathrm{L}$ lower than $195 \mathrm{mg} / \mathrm{L}$ of SBR, lifted by 33\%. Meanwhile, PHA content was $22.4 \mathrm{mg}$ COD/gVSS in the sludge at the end of nitrification using the SBBR system due to the presence of biofilm, which was higher than $21.5 \mathrm{mg}$ COD/gVSS of the SBR system. The second one is different cycle times. The nitrogen removal effect of denitrifying bacteria could be maximized in the presence of biofilm, resulting in significantly increased efficiency of nitrogen removal. The nitrogen removal effect of SBBR treating diafiltration with the same total nitrogen concentration was equivalent to that of SBR. However, the time of nitrogen removal was improved by $16.7 \%$ compared with SBR.

\section{Conclusions and Recommendations}

After 110 days of landfill leachate nitrogen removal tests, the following conclusions can be made:

(1) The effluent COD of SBR and SBBR stabilized at $650 \pm 50 \mathrm{mg} / \mathrm{L}$, with the removal rate of organic matter expressed as COD of the leachate stabilized at about $85 \%$.

(2) The nitrogen removal effect of activated sludge on leachate was substantially increased through improving the operating modes of SBR and SBBR. The total nitrogen of SBR and SBBR in the effluent was less than $40 \mathrm{mg} / \mathrm{L}$; meanwhile, the removal rate of total 
nitrogen in the leachate reached up to $95 \%$ without any external carbon source using the two systems.

(3) SBBR achieves the advanced nitrogen removal of landfill leachate mainly through SND, whereas SBR achieves the advanced nitrogen removal of landfill leachate mainly through endogenous denitrification. The nitrogen removal amount ranging from $150 \mathrm{mg} / \mathrm{L}$ to $160 \mathrm{mg} / \mathrm{L}$ with SND can be implemented through the aerobic-anoxic microenvironment of biofilm in SBBR, which was up by $40-50 \%$ in comparison to SBR.

(4) Compared with the SBR process, biological stuffing was added in the SBBR. Although the filler occupies the space of the reactor, the biofilm biomass on the filler is large, including many nitrification and denitrification bacteria, which improves the nitrification and denitrification efficiency of the system. The presence of biofilm improves not only the SND effect of SBBR but also the utilization of carbon sources of the sludge, further enhancing the nitrogen removal efficiency of the whole system. Compared with the SBR process, the reaction cycle of SBBR was shortened by $4 \mathrm{~h}$ with the nitrogen removal efficiency improved by $16.7 \%$.

Author Contributions: Conceptualization, J.J., L.M., L.H. and K.W.; methodology, K.W. and J.J.; validation, J.J. and D.W.; formal analysis, J.J., L.M. and L.H.; investigation, J.J.; data curation, J.J. and L.H.; writing — original draft preparation, J.J.; funding acquisition, K.W. All authors have read and agreed to the published version of the manuscript.

Funding: This project received funding from the Natural Science Foundation of Shandong Province (ZR2017BEE067), Natural Science Foundation of Shandong Province (ZR2018BEE036), Natural Science Foundation of Shandong Province (ZR2019BEE058), National Key Research and Development Program of China (2017YFF0209903).

Conflicts of Interest: The authors declare that they have no conflict of interest.

\section{References}

1. Amor, C.; Torres-Socías, E.D.; Peres, J.A. Mature landfill leachate treatment by coagulation/flocculation combined with Fenton and solar photo-Fenton processes. J. Hazard. Mater. 2014, 286, 261-268. [CrossRef]

2. Renou, S.; Givaudan, J.G.; Poulain, S.; Dirassouyan, F.; Moulin, P. Landfill leachate treatment: Review and opportunity. J. Hazard. Mater. 2008, 150, 468-493. [CrossRef] [PubMed]

3. Marttinen, S.K.; Kettunen, R.H.; Sormunen, K.M.; Soimoasuo, R.M.; Rintala, J.A. Screening of physica-chemical methods for removal of organic material, nitrogen and toxicity from low strength landfill leachates. Chemosphere 2002, 46, 851-858. [CrossRef]

4. Tiago, H.M.; Theo SO, S.; Eugenio, F. Ammonium removal from landfill leachate by Clinoptilolite adsorption followed by bioregeneration. J. Environ. Chem. Eng. 2017, 5, 63-68.

5. Sun, H.W.; LÜ, X.T.; Peng, Y.Z.; Wang, S.Y.; Ma, J. Long-term nitritation performance of ammonium-rich landfill leachate. Chin. J. Chem. Eng. 2015, 23, 1888-1893. [CrossRef]

6. Gabarró, J.; Ganigué, R.; Gich, F.; Ruscalleda, M.; Balaguer, M.D.; Colprim, J. Effect of temperature on AOB activity of a partial nitritation SBR treating landfill leachate with extremely high nitrogen concentration. Bioresour. Technol. 2012, 126, 283-289. [CrossRef]

7. Kennedy, K.J.; Lentz, E.M. Treatment of landfill leachate using sequencing batch and continuous flow upflow anaerobic sludge blanket (UASB) reactors. Water Res. 2000, 34, 3640-3656. [CrossRef]

8. Zhang, L.; Xu, K.C.; Peng, Y.Z. Composition characterization and transformationmechanism of refractory dissolved organic matter from an ANAMMOX reactor fedwith mature landfill leachate. Bioresour. Technol. 2018, 250, 413-421.

9. Miao, L.; Wang, S.Y.; Li, B.K.; Cao, T.H.; Zhang, F.Z.; Wang, C.; Peng, Y.Z. Effect ofcarbon source type on intracellular stored polymers during endogenous denitritation(ED) treating landfill leachate. Water Res. 2016, 100, 405-412. [CrossRef]

10. Yang, Q.; Peng, Y.Z.; Liu, X.H.; Zeng, W.; Mino, T.; Satoh, H. Nitrogen removal vianitrite from municipal wastewater at low temperatures using real-time control tooptimize nitrifying communities. Environ. Sci. Technol. 2017, 41, 8159-8164. [CrossRef] [PubMed]

11. Wang, K.; Wang, S.Y.; Zhu, R.L.; Miao, L.; Peng, Y.Z. Advanced nitrogen removal from landfill leachate without addition of external carbon using a novel systemcoupling ASBR and modified SBR. Bioresour. Technol. 2013, 134, 212-218. [CrossRef]

12. Li, H.S.; Zhou, S.Q.; Ma, W.H.; Huang, P.F.; Huang, G.T.; Qin, Y.J.; Xu, B.; Hai, O.Y. Long-term performance and microbial ecology of a two-stage PN-ANAMMOXprocess treating mature landfill leachate. Bioresour. Technol. 2014, 159, 404-411. [CrossRef] [PubMed]

13. Ma, B.; Wang, S.Y.; Cao, S.B.; Miao, M.M.; Jia, F.X.; Du, R.; Peng, Y.Z. Biologicalnitrogen removal from sewage via anammox recent advances. Bioresour. Technol. 2016, 200, 981-990. [CrossRef] 
14. Peng, Y.Z.; Zhang, S.J.; Zeng, W.; Zheng, S.; Mino, T.; Satoh, H. Organic removal by denitritation and methanogenesis and nitrogen removal by nitritation from landfill leachate. Water Res. 2008, 42, 883-892. [CrossRef]

15. Luo, Z.Y.; Chen, W.M.; Wen, P.; Jiang, G.B.; Li, Q.B. Impact of leachate recirculation frequency on the conversion of carbon and nitrogen in a semi-aerobic bioreactor landfill. Environ. Sci. Pollut. Res. 2019, 26, 13354-13365. [CrossRef] [PubMed]

16. Zhu, R.L.; Wang, S.Y.; Li, J.; Wang, K.; Miao, L.; Ma, B.; Peng, Y.Z. Biologicalnitrogen removal from landfill leachate using anaerobic-aerobic process: Denitrita-tion via organics in raw leachate and intracellular storage polymers of microorganisms. Bioresour. Technol. 2013, 128, 401-408. [CrossRef] [PubMed]

17. Miao, L.; Wang, S.Y.; Zhu RLCao, T.H.; Peng, Y.Z. The effect of oxygen supplyon nitrogen removal via nitrite using stored substrate (PHB) as the electron donor in SBRs. Biochem. Eng. J. 2015, 103, 130-137. [CrossRef]

18. Miao, L.; Yang, G.Q.; Tao, T.; Peng, Y.Z. Recent advances in nitrogen removal from landfill leachate using biological treatments-A review. J. Environ. Manag. 2019, 235, 179-185. [CrossRef]

19. Krishna, C.; Loosdrecht MC, M.V. Effect of temperature on storage polymers and settle ability of activated sludge. Water Res. 1999, 33, 2374-2382. [CrossRef]

20. Takabatake, H.; Satoh, H.; Mino, T.; Matsuo, T. Recovery of biodegradable plastics from activated sludge process. Water Sci. Technol. 2000, 42, 351-356. [CrossRef]

21. Chiu, Y.C.; Lee, L.L.; Chang, C.N.; Chao, A.C. Control of carbon and ammonium ratio for simultaneous nitrification and denitrification in a sequencing batch bioreactor. Int. Biodeterior. Biodegrad. 2007, 59, 1-7. [CrossRef]

22. Yin, J.; Zhang, P.Y.; Li, F.; Li, G.P.; Hai, B.H. Simultaneous biological nitrogen and phosphorus removal with a sequencing batch reactor biofilm system. Int. Biodeterior. Biodegrad. 2015, 103, 221-226. [CrossRef]

23. Beun, J.J.; Paletta, F.; Van Loosdrecht MC, M.V.; Heijnen, J.J. Stoichiometry and kinetics of poly-beta-hydroxybutyrate metabolism in aerobic, slow growing, activated sludge cultures. Biotechnol. Bioeng. 2000, 67, 379-384. [CrossRef]

24. Third, K.A.; Burnett, N.R.; Cord-Ruwisch, R. Simultaneous nitrification and denitrification using stored substrate (PHB) as the electron donor in an SBR. Biotechnol. Bioeng. 2003, 83, 706-720. [CrossRef] [PubMed]

25. Li, J.; Peng, Y.Z.; Gu, G.W. Factors affecting simultaneous nitrification and denitrification in an SBBR treating domestic wastewater. Front. Environ. Sci. Eng. China 2007, 1, 246-250. [CrossRef]

26. APHA. Standard Methods for the Examination of Water and Wastewater; American Public Health Association: New York, NY, USA, 1995.

27. Albuquerque, M.G.E.; Eiroa, M.; Torres, C.; Nunes, B.R.; Reis, M.A.M. Strategies for the development of a side stream process for polyhydroxyalkanoate (PHA) production from sugar cane molasses. J. Biotechnol. 2007, 130, 411-421. [CrossRef] 